\title{
Bank Loan Sales: A New Look at the Motivations for Secondary Market Activity
}

\author{
Rebecca S. Demsetz * \\ Federal Reserve Bank of New York \\ 33 Liberty Street \\ New York, NY 10045 \\ rebecca.demsetz@ny.frb.org \\ 212-720-5740
}

\footnotetext{
* The views expressed in this paper are the author's and not necessarily those of the Federal Reserve Bank of New York or the Federal Reserve System. Richard Cantor, Jean Helwege, Beverly Hirtle, Stavros Peristiani, Marc Saidenberg, Phil Strahan, and participants of the Empirical Methods Seminar at the Board of Governors of the Federal Reserve provided many helpful comments on earlier drafts. Kevin Leyh and Oba McMillan provided able research assistance.
} 


\title{
Bank Loan Sales: A New Look at the Motivations for Secondary Market Activity
}

\begin{abstract}
Bank lending traditionally involves the extension of credit that is held by the originating bank until maturity. Loan sales allow banks to deviate from this pattern by transferring loans in part or in their entirety from their own books to those of another institution. This paper uses a new methodology to test the validity of two hypotheses regarding banks' motivations for selling and buying loans: (1) the comparative advantage hypothesis, that banks with a comparative advantage in originating loans sell and those with a comparative advantage in funding loans buy, and (2) the diversification hypothesis, that banks lacking the ability to diversify internally use loan sales and purchases to achieve diversification. A third hypothesis -- that reputational barriers can limit access to the secondary market -- is considered as well, with particular attention paid to the importance of affiliate relationships in explaining secondary market activity. Together, the evidence relating to these three hypotheses helps clarify the benefits of an active secondary loan market. It also generates predictions regarding the future of that market in a world of rapid consolidation and disappearing barriers to geographical expansion.
\end{abstract}




\section{Introduction}

Bank lending traditionally involves the extension of credit that is held by the originating bank until maturity. Loan sales allow banks to deviate from this pattern by transferring loans in part or in their entirety from their own books to those of another institution. The dramatic expansion of secondary loan markets has led to a growing literature on the topic, one goal of which is to understand which banks sell loans and why.

This paper presents new evidence on the comparative advantage hypothesis, that banks with a comparative advantage in originating loans sell and those with a comparative advantage in funding loans buy, and the diversification hypothesis, that banks lacking the ability to diversify internally use loan sales and purchases to enhance diversification. A third hypothesis -- that reputational barriers can limit access to the secondary market -- is considered as well, with particular attention paid to the importance of affiliate relationships in explaining secondary market activity. Together, the evidence relating to these three hypotheses helps clarify the benefits of an active secondary loan market. It also generates predictions regarding the future of that market in a world of rapid consolidation and disappearing barriers to interstate branching.

Existing empirical studies investigating the motivations for loan sales activity (particularly, the sale of commercial and industrial loans) typically regress the dollar volume of loan sales or an indicator variable for positive sales activity on a set of bank characteristics. ${ }^{1}$ The results from these regressions have been used to determine which banks sell loans and why. Particular emphasis has been placed on the role of capital ratios, funding costs, and origination

1 For example, see Pavel and Philis (1987), Berger and Udell (1993), Demsetz (1994) and Haubrich and Thomson (1996). Haubrich and Thomson also estimate a second regression with loan purchases as the dependent variable. 
opportunities, since these variables distinguish banks with a comparative advantage in loan funding from those with a comparative advantage in loan origination.

The problem with this approach is that many banks are concurrently active on both the sell side and the buy side of the secondary market. This suggests that diversification may rival comparative advantage as a motivation for loan sales. Moreover, it complicates tests of the comparative advantage hypothesis. Characteristics that increase a bank's propensity to sell loans may also increase their propensity to buy loans. Their primary effect may be to enhance secondary market activity in general, rather than sell-side activity or buy-side activity in particular. When banks are simultaneously selling and buying, gross sales or purchase volume says little about a bank's net position in the secondary market, and therefore provides little evidence regarding the comparative advantage hypothesis.

This paper tests the comparative advantage and diversification hypotheses using a different estimation technique. I divide banks into four mutually exclusive groups: (1) banks that sell loans and buy loans; (2) banks that only sell loans; (3) banks that only buy loans; and (4) banks that neither sell nor buy loans. Using a multinomial logit estimation, I examine the effects of a variety of bank characteristics on the probability that a bank falls into each of the first three groups (the three participant groups) relative to the fourth group (non-participants). From the multinomial logit estimates, it is easy to calculate a second set of estimates describing the effects of the same independent variables on the probability that a bank falls into the sell-only group relative to the buy-only group.

Differentiating between types of secondary market activity ("buy only," "sell only," or "buy and sell") proves very useful. With the mulitnomial logit estimates, I am able to subject the 
comparative advantage hypothesis to a simple and direct test: Do origination opportunities and funding constraints increase the probability that a given bank belongs to the sell-only group relative to the buy-only group? The same estimates can be used to evaluate the diversification hypothesis with a simple and direct test: Do limitations on internal diversification enhance the probability that a given bank participates as a concurrent buyer and seller? Finally, reputational barriers can be investigated by identifying those variables that diminish participation, particularly on the sell side, where reputation should be most important.

The analysis uses bank-level data from the Reports of Condition and Income (Call Reports). The data are available for all commercial banks between 1988 and 1993 and are described in Section III after a review of the relevant literature. Section IV describes the multinomial logit model and the variables associated with the comparative advantage hypothesis, the diversification hypothesis, and barriers to participation.

The results, presented in Sections V and VI, confirm both the comparative advantage hypothesis and the diversification hypothesis and are robust to alternative definitions for the selland-buy, sell-only, and buy-only groups. Consistent with the comparative advantage hypothesis, I find that capital strength significantly diminishes the likelihood that a bank is in the sell-only group relative to the buy-only group and that strong loan origination opportunities (proxied by statelevel economic conditions) significantly enhances the likelihood that a bank is in the sell-only group relative to the buy-only group. Concentration in C\&I lending, a second possible proxy for origination opportunities, also significantly enhances the likelihood that a bank is in the sell-only group relative to the buy-only group. Reliance on costly funding (uninsured deposits, brokered deposits, and federal funds) enhances the likelihood that a bank is in the sell-only group, but this 
result is only marginally significant.

Consistent with the diversification hypothesis, I find that banks with good opportunities for diversified originations (those for whom extensive branching is permissible) are significantly less likely to participate in the loan sales market, especially as concurrent buyers and sellers. The economic impact of variables proxying diversification opportunities is strong. For instance, the ability to branch statewide is associated with a 10 percentage point decrease in the predicted probability that a bank will participate as a buyer and seller, where all other regression variables are held constant at their median values. This exceeds the economic impact associated with variables proxying origination opportunities and funding constraints and suggests that recent increases in the opportunities for interstate expansion at the bank level may reduce secondary market activity.

I also find evidence of reputational barriers to secondary market participation. Issuance of standby letters of credit (used as a proxy for strong credit quality reputation) significantly enhances the likelihood that a bank participates on the sell side of the market, in either the sellonly group or the sell-and-buy group. Membership in a multi-bank holding company (a way for banks to overcome reputational barriers to participation) significantly enhances the likelihood that a bank participates as a buyer or seller. Again, the economic importance of the effect is strong, with membership in a multibank holding company leading to a 23 percentage point increase in the probability of participation in the buy-and-sell group, far exceeding the economic impact of variables associated with the comparative advantage hypothesis. This suggests that holding company acquisition may enhance secondary market activity by increasing the fraction of banks with holding company affiliation. Of course, to the extent that consolidation goes beyond holding 
company acquisition and actually eliminates bank charters, the opposite prediction holds.

The importance of multi-bank holding company membership has been identified in several papers (Pavel and Philis 1987, Berger and Udell 1993, Demsetz 1994, and Haubrich and Thomson 1996). Since the Call Report fails to identify the party on the opposite side of a given transaction, these papers stop here. However, additional relevant information on affiliate relationships can be collected from the Call Report. In particular, it is possible to determine whether a given bank's affiliates are active as loan sellers or buyers. Section 7 incorporates this information into the mulitnomial logit model to gain a better understanding of the role of affiliate relationships in explaining secondary market activity.

\section{Related Literature}

Background information on the loan sales market is available in detail in Gorton and Haubrich (1990). The theoretical and empirical literature addresses a variety of questions, including why the loan sales market exists, how the market overcomes problems stemming from information asymmetries, and whether loan sales are risk-reducing or risk-enhancing. Eight theories of securitization (with several implications relating to loan sales) are summarized in Berger and Udell (1993). Their paper describes each of these theories in the context of a thorough literature review, which I will not repeat here. ${ }^{2}$

2 There is considerable overlap between the theories discussed by Berger and Udell (1995) and those tested here. Berger and Udell discuss the "comparative advantage" hypothesis, which is a focus of this paper. Their "regulatory tax" hypothesis has time series implications, but in a cross-sectional setting, it resembles the funding-constraints side of the comparative advantage hypothesis in that banks facing binding capital constraints have a comparative disadvantage in funding loans and should therefore fall on the sell side of secondary market transactions. Several of the other hypotheses discussed by Berger and Udell (the "monitoring technology" hypothesis, the "collateralization" hypothesis, the "moral hazard" hypothesis, and the "liquidity" hypothesis) yield predictions regarding the relationship between bank risk and loan sales activity. Similar 
Of particular relevance to this paper are prior works addressing the motivations for loan sales and purchases and the barriers to secondary market participation. Two theoretical papers yield especially pertinent predictions regarding which banks sell loans and which banks buy loans. Pennacchi (1988) first formalized the proposition subsequently labeled the "comparative advantage hypothesis": Selling banks are characterized as those with a comparative advantage in originating loans and a comparative disadvantage in funding loans, and buying banks have the opposite characterization. Carlstrom and Samolyk (1995) assume that banks have a comparative advantage in identifying profitable projects in their own locality, and show that funding constrained banks with profitable local lending opportunities should sell loans to unconstrained banks in other localities. Their model generates the prediction that "banks that are capital constrained in the face of high loan demand are more likely to engage in loan sales." Again, loan buyers have the opposite characterization.

A competing (but not inconsistent) hypothesis is that banks use the secondary market to diversify their loan portfolios. The diversification motive can be thought of as a special case of the comparative advantage motive when the source of a bank's origination advantage is proximity to local lending opportunities (as in Carlstrom and Samolyk 1995). ${ }^{3}$ In the more general case, the predictions that follow from the two hypotheses are very different. The diversification hypothesis predicts that banks with limited opportunities for diversified originations (attributable to size or limitations on geographical expansion) are most likely to participate in the secondary market.

predictions are generated here through my consideration of reputational barriers to secondary market participation.

3 Actually, Carlstrom and Samolyk (1995) interpret a bank's "locality" quite broadly. It may correspond to geographical location but may also refer to some other type of specialization. 
Moreover, these banks are likely to participate on both the buy and sell side of the market, since they are not using the secondary market to facilitate growth or shrinkage of the loan portfolio. Rather, they use loan sales and purchases to rebalance a portfolio of a given size.

Regardless of the motivation for loan sales or purchases, realized secondary market activity should also reflect any barriers to participation. The absence of explicit recourse for loans sold raises both moral hazard and adverse selection problems. Pennacchi (1988) and Gorton and Pennacchi (1995) consider contractual features that facilitate loan sale in the presence of these problems. Particularly compelling is the practice of retaining a share of the loan in question, which provides the seller with an incentive to monitor the borrower. A strong credit quality reputation may improve access to the secondary market, particularly as a loan seller.

Turning to the empirical literature, Pavel and Philis (1987), Berger and Udell (1993), Demsetz (1994), and Haubrich and Thomson (1996) each provide some evidence relating to the comparative advantage hypothesis. All four find that banks with low capital and high funding costs are more active loan sellers. Demsetz (1994) also finds that proxies for local origination opportunities positively affect sales volume. These results appear to support the comparative advantage hypothesis. However, Haubrich and Thomson (1996) find that capital is negatively related to loan purchase activity, which is the opposite of what the comparative advantage story would predict.

Tests of the diversification motive have received less emphasis in the empirical literature. Pavel and Philis (1987) find a positive relationship between loan sales and loan portfolio concentration, suggestive of a diversification motive; however, their measure of concentration is based on the portfolio shares of ten broad lending groups. Since the Call Report data primarily 
capture the sale of commercial and industrial (C\&I) loans, the link between Pavel and Philis' concentration variable and their loan sales variable is difficult to interpret. Berger and Udell (1993) examine the relationship between loan sales and bank risk. Recognizing that sales activity can be motivated by a need to diversify, they include indicator variables for banks located in states with unit branching and limited branching. In order to save space, however, Berger and Udell do not report the coefficients on these control variables. Moreover, both Berger and Udell and Pavel and Philis look at loan sales but not purchases. This makes it especially difficult to draw inferences regarding the diversification motive.

The empirical papers discussed above also include some evidence regarding reputational barriers to participation. Berger and Udell (1993) find that variables measuring bank risk are generally not related to sales activity, which suggests that riskier banks are not excluded from the loan sales market. On the other hand, each paper includes an indicator variable that controls for membership in a multi-bank holding company and, where its coefficient is reported, it is positive and significant in both sales and purchase equations. This suggests that holding company membership may help banks overcome barriers to secondary market participation by lessening information asymmetries.

This paper extends the existing empirical literature in several ways. Additional bank characteristics are considered and, most important, a different estimation approach is adopted. Existing work attempts to draw implications regarding the comparative advantage hypothesis using data on gross sales or gross purchase activity. But characteristics that increase a bank's propensity to sell may also increase its propensity to buy, with little net effect on its sales or purchase orientation. 
A better approach is to look at the determinants of sales and purchase activity jointly. I divide banks into four groups: (1) those that sell and buy; (2) those that only sell; (3) those that only buy; and (4) those that neither sell nor buy. Using a multinomial logit estimation, I examine the effects of a variety of bank characteristics on the probability that a bank falls into each of the first three groups (the three participant groups) relative to the fourth group (non-participants). From the multinomial logit estimates, it is easy to determine whether origination opportunities and funding constraints increase the probability that a given bank belongs to the sell-only group relative to the buy-only group. This constitutes a much more appropriate test of the comparative advantage hypothesis.

Differentiating between types of secondary market activity ("buy only," "sell only," or "buy and sell") also facilitates tests of the diversification hypothesis. In particular, I can determine whether limitations on internal diversification enhance the probability that a given bank participates as a concurrent buyer and seller. These limitations are measured directly using information on the branching restrictions in the state of operation and the size of a particular bank's branch network. They are also measured indirectly by allowing for nonlinearities in the relationship between bank size and secondary market activity.

I draw conclusions regarding reputational barriers to secondary market participation by identifying variables that diminish the likelihood of participation, particularly on the sell side, where reputation should be most important. I include several variables related to bank risk and reputation but also emphasize that much can be learned by taking a closer look at the role of affiliate relationships, which can help banks overcome reputational barriers to participation. Existing studies control for holding company membership but include no information on the 
secondary market activity of a given bank's affiliates. In contrast, I interact the indicator variable for multi-bank holding company membership with a second indicator variable signifying secondary market activity on the part of affiliates. This yields firmer conclusions regarding the role of affiliate relationships in reducing barriers to secondary market participation and, more generally, speaks to the importance of loan markets internal to the holding company.

Finally, I examine the economic impact of each independent variable to draw conclusions regarding the relative importance of the alternative motivations and constraints affecting sales and purchase activity.

\section{Data}

Bank-level data on quarterly sales and purchases of C\&I loans are available from banks' Reports of Condition and Income, or "Call Reports," between 1988 and 1993. ${ }^{4}$ Equivalent data are not available at the holding company level, so I proceed under the assumption that the bank is an appropriate decision-making unit to consider. One might argue that the holding company is also an appropriate decision-making unit, though an analysis of secondary market transactions at the holding company level would have nothing to say about internal loan markets and would yield few predictions regarding the effect of holding company acquisitions on the future of the secondary market. Both subjects are treated below.

The Call Report loan sales item provides the dollar volume of loans participated or sold during the calendar quarter. ${ }^{5}$ Banks include only loans sold without recourse (loans that they can

${ }^{4} 1988$ is the first year in which both sales and purchase data are available, though sales data are available beginning in 1986. Both series end in 1993.

5 This includes portions of loans sold by banks facing binding legal lending limits. 
remove from their books) and only loans that they have originated. ${ }^{6}$ Lead banks in a syndication are instructed not to include shares taken on by syndicate members. The loan purchase item describes the dollar volume of loans or participations in loans that have been purchased during the calendar quarter. Again, syndicate participants' shares of syndicated loans should not be included.

The Call Report does not explicitly refer to the sales and purchase series as a C\&I series, but they are commonly interpreted as such since both exclude loans to individuals and loans secured by one-to-four family residential properties -- loans that are frequently packaged (bundled and guaranteed) into marketable securities -- leaving primarily C\&I loans. These loans can be sold to a variety of buyers, including other banks within the seller's holding company, unrelated banks, foreign banks, and even non-bank institutions (Cantor and Demsetz 1993).

Table 1 presents summary statistics on loan sales and purchase volume, though for the purposes of this study, volume data are used only to sort banks into the four groups depicted there. One could examine continuous variation in loan sales or purchase volume but the distinction between the four groups in Table 1 provides more insight into the comparative advantage hypothesis, the diversification hypothesis, and barriers to participation. ${ }^{7}$ About onethird of the bank-year observations underlying Table 1 fall into the "neither buy nor sell" category.

${ }^{6}$ As Gorton and Haubrich (1990) explain, loans are typically sold without recourse. The selling bank continues to service the loan but passes interest payments along to the buyer.

${ }^{7}$ Moreover, a problem with the Call Report data on sales and purchase volumes is that they do not reflect loan maturity. For instance, one bank may sell three $\$ 1$ million loans, each with 1-month maturity, thereby reporting sales volume of $\$ 3$ million. Another bank selling one $\$ 1$ million loan with 3-month maturity will report sales volume of $\$ 1$ million. The Call Report data suggest that the second bank is a less active loan seller, while in a sense the sales activities of the two banks may be viewed as similar. 
Among those banks that do participate, "buy and sell" is the most common behavior; however, a non-trivial fraction of the sample participates as only a seller or only a buyer. Comparing observations for a given bank over time, banks remain in the same category in consecutive years over 60 percent of the time. When transitions do occur, no transition stands out as particularly common.

The empirical work that follows is based on Call Report data for all but the largest insured domestic commercial banks. Banks with total assets exceeding \$20 billion are excluded because of the very different nature of their lending activity and secondary market activity. These banks commonly lend in a national market rather than a local or regional market. Hence, there is little cross-sectional variation in their loan origination opportunities. In terms of secondary market activity, some of the largest banks behave as "market makers," buying or selling loans with the intent of immediately reversing that trade with a subsequent counterparty. They account for a large fraction of aggregate sales volume, and are therefore important in understanding aggregate sales trends (Berger and Udell 1993, Demsetz 1993, Haubrich and Thomson 1996), but they shed little light on the cross-sectional patterns implied by the comparative advantage hypothesis. Their numbers are few, and their exclusion leads to no qualitative changes in the reported results. ${ }^{8}$

\section{Methodology}

${ }^{8}$ An additional reason to exclude the largest banks from the analysis is that loan sales reported by these institutions are suspiciously large relative to loan purchases. It is possible that a handful of very large banks erroneously included in their loan sales figures loans that they arranged but that were actually originated by other banks through syndications. Otherwise the loan sales and purchase figures for the largest banks suggest that almost all of their sales were purchased by smaller banks, foreign banks, or non-bank institutions. While the Federal Reserve's Senior Loan Officers Survey of Lending Practices confirms that these buyers are important, their role seems vastly exaggerated by the Call Report figures reported by the largest banks. 
A multinomial logit model is used to identify characteristics related to participation in the loan sales market as either a seller, a buyer, or both. There are four groups to which a given bank may belong: (1) buy and sell, (2) sell only, (3) buy only, and (4) neither buy nor sell. Using maximum likelihood estimation, the multinomial logit model simultaneously fits the following three equations:

$$
\frac{\text { Prob(bank } i \in \text { group } 1)}{\text { Prob(bank } i \in \text { group } 4)}=e^{X_{i} \beta_{1}}
$$

$$
\frac{\operatorname{Prob}(\text { bank } i \in \operatorname{group} 2)}{\operatorname{Prob}(\text { bank } i \in \operatorname{group} 4)}=e^{X_{i} \beta_{2}}
$$

$$
\frac{\text { Prob(bank } i \in \text { group } 3)}{\text { Prob(bank } i \in \text { group } 4)}=e^{X_{i} \beta_{3}}
$$

where $X$ is a vector of independent variables and $\beta_{1}, \beta_{2}$, and $\beta_{3}$ are vectors of estimated coefficients. Each estimated coefficient gives the change in the relevant log-odds ratio for a oneunit change in the corresponding independent variable.

By comparing coefficients from any two of the three above equations, one can determine the change in alternative log-odds ratios for a one-unit change in the corresponding independent variable. For instance, subtracting Equation 3 coefficients from Equation 2 coefficients gives estimates of the independent variables' effects on the probability that bank "I" is in group 2 relative to the probability that bank "I" is in group 3: 


$$
\frac{\operatorname{Prob}(\text { bank } i \in \text { group } 2)}{\text { Prob(bank } i \in \text { group } 3)}=e^{X_{i}\left(\beta_{2}-\beta_{3}\right)}
$$

This particular comparison provides a straightforward test of the comparative advantage hypothesis, which predicts that lending opportunities and funding constraints should increase the probability of being in the sell-only group (group 2) relative to the buy-only group (group 3). At the same time, the multinomial logit estimates provide tests of the diversification motive (particularly Equation 1) and provide information regarding barriers to secondary market participation on either the buy side or the sell side. The advantage of the multinomial logit model over a simple logit or probit model (as in Pavel and Philis 1987) is that it allows the independent variables to have different effects on different participatory behaviors.

In the remainder of this section, I describe the variables included in $X$. I divide $X$ into four groups: (1) variables related to the comparative advantage hypothesis; (2) variables related to the diversification motive; (3) variables related to participation barriers; and (4) bank size. Bank size is treated separately because it may affect secondary market participation for comparative advantage reasons, diversification reasons, or through its relationship to participation barriers. Variables related to the comparative advantage hypothesis

The comparative advantage hypothesis suggests that both funding constraints and loan origination opportunities will increase the probability that a given bank is in the sell-only group relative to the buy-only group. Commonly used measures of funding constraints include a capital ratio and a "hot funds" ratio. The latter measures the use of costly funding. I include both ratios, where the capital ratio is measured as equity capital divided by assets and the hot funds 
ratio is measured as the sum of brokered deposits, uninsured deposits (deposits exceeding the $\$ 100,000$ insurance cap), and federal funds purchased, divided by assets. The capital ratio is measured with a lag. Greater detail on the time structure of the regressions is provided below.

I also include two proxies for loan origination opportunities: state labor force growth (calculated as a percentage change) and state unemployment rate. Both are measured for the state in which a given bank is headquartered, and are intended to capture the availability of profitable local lending opportunities.

Berger and Udell (1993) suggest the C\&I loans-to-assets ratio as an alternative measure of origination opportunities. I include the lagged value of this ratio, but since originated loans may end up being sold off the books, and loans on the books may have been purchased from other banks, I am somewhat hesitant to interpret it as a measure of origination opportunities. The C\&I loan ratio may be an important determinant of secondary market activity simply because the loan sales and purchases captured by the Call Report data are sales and purchases of C\&I loans. Banks whose portfolios are concentration in other loan types are less likely to participate. Variables related to the diversification motive

Banks with poor opportunities for diversified originations can improve the industrial or geographic mix of loans in their C\&I portfolio without greatly altering the size of their portfolio by concurrently buying and selling loans. In include three variables intended to proxy for diversified origination opportunities. The first is a dummy variable equal to one for banks located in states permitting statewide branching. With greater potential for geographically diverse originations, these banks may rely less heavily on the loan sales market to achieve their diversification goals. A second variable proxying diversification potential is the size of a bank's 
branch network, measured as the log of the number of bank branches. Again, banks with an expansive branch network may rely less heavily on the secondary market as a way to develop a diversified portfolio. The third variable related to diversification is a dummy variable equal to one for banks located in states permitting interstate expansion through the holding company structure. ${ }^{9}$ If concerns regarding diversification are relevant at the level of the holding company, interstate structure may again substitute for the secondary market as a means by which to achieve a desired level of diversification. ${ }^{10}$

\section{Variables related to participation barriers}

The absence of explicit recourse may lead loan buyers to shy away from sellers with poor or unknown asset quality. Hence, measures of asset quality may help explain participation on the sell side of the market. Two variables are included as direct measures of asset quality: a nonperforming loan ratio (nonaccruals plus loans past due 90 or more days, divided by assets) and a net charge-off ratio (charge-offs minus recoveries, divided by assets). A third ratio -- net issuance of standby letters of credit (standbys minus standbys conveyed to others through participations, divided by assets) -- is used as a proxy for a bank's credit quality reputation. The market's acceptance of a given bank as a backer of credit suggests that the bank has a reasonable

\footnotetext{
${ }^{9}$ Both the statewide branching dummy and the interstate expansion dummy are from Berger, Kashyap, and Scalise (1995), Table B6.

${ }^{10}$ Note that sales or purchases between holding company affiliates are included in the Call Report sales and purchase series. If transfers of loans among the commercial bank subsidiaries of a holding company are more likely in geographically expansive holding companies, then the interstate expansion variable may be positively related to secondary market activity rather than negatively related to secondary market activity. I control for membership in a multibank holding company using a dummy variable, described below.
} 
reputation for credit quality. ${ }^{11}$

I also include a dummy variable identifying banks that belong to a multi-bank holding company. If transactions between holding company affiliates are not subject to the information asymmetries that can complicate non-affiliate transactions, membership in a multibank holding company may help explain participation on both the sell-side and buy-side of the market. I investigate the importance of affiliate transactions further in Section 7.

\section{Bank Size}

Bank size (total assets) may affect secondary market participation for a variety of reasons. Pennacchi (1988) argues that large banks have comparatively strong lending opportunities and comparatively high funding costs, and therefore should participate on the sell side of the market. But the diversification motive suggests an additional role for size: If the smallest banks have limited opportunities for diversified originations, they may be relatively active participants on both the buy side and the sell side of the market. Or, if the smallest banks face binding legal lending limits, they may participate in the sell-only group. Finally, fixed costs associated with both sales and purchases may lead to more frequent participation by larger banks on both sides of the market. $^{12}$

Since each of these stories has different implications for the role of asset size, I use a flexible specification that includes a set of eight asset size dummy variables, corresponding to the

11 Berger and Udell (1993) draw a parallel between loan sales and standby letters of credit. They consider both to be forms of securitization, with standbys ("off-balance sheet securitization") resulting in banks that hold credit risk without supplying the underlying funds.

${ }^{12}$ Table 1 reports mean size by participation group. The average size of banks participating as buyers or sellers exceeds that of non-participants and the average size of banks in the buy-and-sell group exceeds that of banks in the buy-only group or the sell-only group. 
asset size groups defined in Table 2. The omitted size dummy corresponds to banks of intermediate size ( $\$ 100$ million to $\$ 500$ million in assets), so the smallest size dummies will have positive coefficients if their dependent variable values exceed those of mid-sized banks, all else equal.

\section{Results}

The model is estimated separately for each year between 1988 and $1993 .{ }^{13}$ Loan sales and purchases are measured by calendar year, so that banks in group 1 either sell loans or buy loans at some point during the calendar year, banks in group 2 sell loans at some point during the calendar year but never buy loans, and banks in group 3 buy loans at some point in the year but never sell loans.

Assets, C\&I loans, capital, nonperforming loans, net charge-offs, and net standby letters of credit are all measured as of the beginning of the year. This helps avoid any confounding effect that loan sales may have on these balance sheet characteristics. The dummy variable measuring membership in a multibank holding company is created using beginning-of-year data as well. Out of necessity, the hot funds variable is measured in mid-year. ${ }^{14}$ State unemployment rate and labor force growth are annual measures corresponding to each calendar year. Dummy variables measuring statewide branching and interstate expansion are based on annual figures, as reported

13 Typically, the panel nature of the Call Report data would prompt estimation using pooled cross sections, with fixed or random firm-effects. However, these procedures are not applicable to the multinomial logit estimation. Since pooling of annual observations without fixed or random effects would overstate significance levels, I choose to report annual estimates instead. This makes for rather dense tables but allows me to establish the robustness of key results over time.

${ }^{14}$ Prior to 1991 , information on uninsured deposits is available only in June Call Reports. 
in Berger, Kashyap, and Scalise (1995). The variable measuring the number of bank branches is based on mid-year data from the Federal Reserve Board's Summary of Deposits database.

Summary statistics for all the independent variables are reported in Table 2. They are based the pooled (1988-1993) data, including 70,490 bank-year observations.

Tables 3 through 6 report results of annual multinomial logit estimations. Table 3 reports the effects of the independent variables on the probability that a bank is in group 1 (sell and buy) relative to group 4 (non-participants); Table 4 reports their effects on the probability that a bank is in group 2 (sell only) relative to group 4; Table 5 reports their effects on the probability that a bank is in group 3 (buy only) relative to group 4 . Table 6 reports the effects of the independent variables on the probability that a bank is in group 2 (sell only) relative to group 3 (buy only). These effects are derived from Tables 4 and 5.

In the next three subsections, I discuss evidence regarding the comparative advantage hypothesis, the diversification hypothesis, and barriers to participation in the secondary market. In the last subsection I evaluate the economic importance of the estimated coefficients (Table 7). Section 6 evaluates the sensitivity of the results to different grouping criteria. Section 7 further explores the importance of affiliate relationships.

\section{Evidence regarding the comparative advantage hypothesis}

Evidence regarding the comparative advantage hypothesis appears in Table 6. The negative and significant coefficients on the capital ratio indicate that banks with strong capital positions have a higher probability of being in the buy-only group relative to the sell-only group. The result is robust in all years except 1992, when the capital coefficient is not significantly different from zero, and is consistent with the comparative advantage hypothesis. The positive 
coefficients on the hot funds ratio are also consistent with the hypothesis -- banks relying on costly funding have a higher probability of being in the sell-only group relative to the buy-only group -- but the hot funds coefficients are significant in only two of the six years.

The comparative advantage hypothesis also predicts that banks flush with lending opportunities should participate as loan sellers while those seeking profitable lending opportunities should participate as loan buyers. Consistent with this prediction, I find that the unemployment rate coefficient is negative and highly significant in each of the six years examined in Table 6. After controlling for capital and reliance on expensive funding, banks located in states with low unemployment rates (proxying strong loan origination opportunities) have a higher probability of being in the sell-only group relative to the buy-only group. My second proxy for loan origination opportunities (state labor force growth) is not robust in Table 6; however, labor force growth may be measured with considerable error at the state level.

The multinomial logit estimates not only support the comparative advantage hypothesis but also reconcile that hypothesis with Haubrich and Thomson's result that capital is inversely related to loan purchase activity. Note that coefficients associated with the capital variable are negative in all three of the participation equations. In other words, capital strength diminishes the likelihood of participation on either side of the market. Capital coefficients in the sell-only equation are consistently more negative than those in the buy-only equation, however, and the differences are significant throughout the sample period. Hence, capital strength enhances the probability that a bank is in the buy-only group relative to the sell-only group, consistent with the comparative advantage hypothesis.

The ratio of C\&I loans to assets positively influences participation on both sides of the 
market, consistent with its role as a proxy for specialization in C\&I lending. Its coefficient is also positive, significant, and robust in Table 6 , indicating that banks with high C\&I loan ratios have a stronger propensity to participate on the sell-side than the buy-side. This helps validate Berger and Udell's interpretation of the C\&I loan ratio as a proxy for origination opportunities.

\section{Evidence regarding the diversification hypothesis}

Coefficients on the statewide branching variable, the interstate branching variable, and the variable measuring the number of bank branches provide evidence regarding the diversification motive. The statewide branching variable is consistently negative and significant in Table 3; banks located in states that do not permit statewide branching are significantly more likely to belong to the buy-and-sell group than the non-participant group. In other words, secondary markets and geographically expansive branch networks appear to be substitute means for achieving portfolio diversification.

Banks located in states that do not permit statewide branching are also more likely to participate in the sell-only group and the buy-only group (though the effect of the statewide branching variable in these equations is significantly smaller than in the buy-and-sell equation). This suggests that geographically expansive branching networks and secondary market activity may also be substitute means for smoothing regional disparities in origination opportunities and funding constraints. Finally, the effect of statewide branching in Table 6 is not very robust. This is consistent with the notion that differences in the behavior of banks in the sell-only group and the buy-only group are explained by comparative advantages and not by differences in diversification potential.

The coefficient associated with the interstate expansion variable tends to be negative in 
each of the participation equations but is less robust than that associated with the statewide branching variable. Interpretation of the interstate expansion coefficient is confounded by the fact that the loan sale and purchase data include sales and purchases between affiliates in a given holding company. Still, the results provide some evidence that secondary market activity substitutes for diversification opportunities at the holding company level.

Results regarding the size of a bank's branch network run contrary to expectations. The number of bank branches does not help distinguish banks that participate in the buy-and-sell group from those that do not participate, as we would expect if banks with many branches had significantly greater opportunities for diversified origination. However, the number of bank branches always has a positive coefficient in Table 6 and is significant in four of six years. This suggests that banks with many branches have a comparative advantage in loan origination, perhaps because proximity to borrowers helps banks identify profitable projects.

\section{Evidence regarding participation barriers}

Tables 3 through 6 also contain evidence on the existence of barriers to participation in the secondary market. Banks that are active issuers of standby letters of credit are significantly more likely to participate on the sell side of the market (in either the sell-and-buy group or the sell-only group) but are no more likely to participate in the buy-only group. The results thus suggest that credit quality significantly enhances a bank's ability to sell loans. Evidence from the nonperforming loan and net charge-off ratios is less strong. Banks with higher charge-off ratios are less likely to participate as either buyers or sellers. Those with higher nonperforming loan ratios are less likely to participate in the buy-and-sell group but otherwise their participation behavior is similar to that of other banks. 
Banks belonging to multibank holding companies are significantly more likely than others to participate on both the buy-side and sell-side of the market. This is consistent with the idea that the information asymmetries leading to reputational barriers are less severe or even nonexistent among holding company affiliates and that banks belonging to holding companies therefore have greater access to counterparties on either side of the loan sales transaction. ${ }^{15}$ When the sample is split by multibank holding company membership, results for each subsample supports the comparative advantage and diversification hypotheses. Moreover, standby letters of credit enhance sales activity for both subsamples, suggesting that credit quality reputation is important even for banks that are holding company members.

\section{Evidence regarding bank size}

Coefficients associated with the size dummies tend to be insignificant with the exception of those estimated for the smallest and largest size groups in certain years. Their signs point to a number of different stories. In Table 3, the size-group coefficients increase at both the low end and the high end of the size distribution. This U-shaped pattern may be explained by a combination of fixed costs to participation (leading to an increase in the probability of participation in the buy-and-sell group among large banks) and the diversification motive (leading to an increase in the same probability among the smallest banks). In Table 4, the size effect becomes linear; small banks are more likely than large banks to participate in the sell-only group. A possible explanation is that small banks may be more likely than large to face binding legal

\footnotetext{
${ }^{15}$ Of course, this story cannot explain the Table 6 result that membership in a multibank holding company increases the likelihood of participating on the buy side relative to the sell side. A possible explanation is that "sell only" banks meeting lending limits through sales to correspondent banks tend not to be holding company members. Unfortunately, I have no way to identify these banks except by size, which is already included in the regression.
} 
lending limits.

Table 5 shows an inverted-U shape to the size-dummy coefficients; the propensity to participate in the buy-only group relative to nonparticipants is highest for banks in the middle of the size distribution. In Table 6, size diminishes the probability of participating in the sell-only group relative to the buy-only group. Note that if size proxies for comparative advantages not already captured by the origination opportunities and funding cost variables, then the Table 6 results suggest that it is the comparative advantage in funding that increases with size.

\section{Interpreting coefficient magnitudes}

On the whole, results in Tables 3 through 6 provide statistical support for the comparative advantage hypothesis and the diversification hypothesis, and suggest the existence of barriers to secondary market participation. Table 7 gives a better sense of the economic effect associated with each of the regressors. The first row reports predicted probabilities corresponding to a "base case" scenario. These are the fitted probabilities that a bank belongs to the buy-and-sell group, the buy-only group, the sell-only group, and the non-participant group when that bank has the median values of each of the continuous variables, does not have access to statewide branching or interstate expansion, and does not belong to a multibank holding company. Median values and parameter estimates are based on pooled (1988-93) data. ${ }^{16}$

The other rows in Table 7 report fitted probabilities when each continuous variable is increased from its median value to its 90th percentile value, and the statewide branching,

${ }^{16}$ Parameter estimates are from a pooled regression with time fixed effects. The constant corresponding to 1990 observations is used in calculating base-case probabilities. For the base case, the size dummy corresponding to the median asset size is set equal to one and all others are set equal to zero. 
interstate expansion, and multibank holding company variables are increased to one, holding all other variables constant at their base-case values. The most striking results are at the bottom of the table. Membership in a multibank holding company increases the probability of participating in the buy-and-sell group by 23 percentage points, at the expense of the sell-only group and the non-participant group. Access to statewide branching and interstate expansion reduce the probability of participating in the buy-and-sell group by 11 and 8 percentage points, respectively, largely in exchange for an increase in the size of the non-participant group. These very strong effects dominate those associated with the other regression variables, including the "comparative advantage" variables (C\&I loan ratio, capital ratio, hot funds ratio, unemployment rate, and labor force growth), for which increases from median values to 90th percentile values generally result in single digit increases or decreases in predicted probabilities. In general, changes in the values of the regressors have a greater impact on the fitted probabilities for the sell-and-buy equation and the non-participant equation than for the sell-only or buy-only equations.

\section{Sensitivity to group definitions}

The analysis thus far has been based on a particular four-way split of the data involving three participatory groups and one non-participatory group. These group definitions have the advantage that they are non-arbitrary, in contrast to alternative definitions in which participants are defined as banks whose sales and/or purchase activity exceeds some positive amount rather than exceeding zero. On the other hand, this definition groups together banks reporting no participation with those reporting a very small amount of participation. This may be viewed as a disadvantage.

As a robustness check, I tried three alternative group definitions. First I defined the buy- 
and-sell group as banks that buy and sell an amount greater than 0.1 percent of assets; the sellonly group as banks that sell an amount greater than 0.1 percent of assets and buy an amount less than 0.1 percent of assets; and the buy-only group as banks that buy an amount greater than 0.1 percent of assets and sell an amount less than 0.1 percent of assets. In this case, the nonparticipant group included banks that neither buy nor sell more than 0.1 percent of assets. I also tried a 0.5 percent cutoff and a one percent cutoff in place of the 0.1 percent cutoff.

In the first two cases, the explanatory power of the multinomial logit model was practically unchanged relative to the model reported here. In the third case (the one percent cutoff) it increased slightly, primarily because of changes in the estimated effect of bank size. When the one percent cutoff is used to define the four groups, the size coefficients always increase significantly at the low end of the asset size distribution, leading to a U-shaped pattern for both the buy-and-sell equation and the buy-only equation, and strengthening the negative linear pattern associated with the size dummies in the sell-only equation. Other changes include a decrease in the unemployment rate coefficient in the buy-only equation, ${ }^{17}$ an increase in the hot funds coefficient in all three equations, and a decrease in the coefficients associated with the number of branches. ${ }^{18}$ Full results are available on request.

I also repeated the Table 7 experiment using the one percent cutoff. The base-case probabilities necessarily change, with more mass in the non-participation group and less mass in the buy-and-sell group, and changes in bank size have a greater effect on predicted probabilities

${ }^{17}$ The significant difference between the unemployment rate coefficients in the buy-only and sell-only equations persists, consistent with the comparative advantage hypothesis.

${ }^{18}$ This makes the effect of numerous branches more significant in the buy-and-sell equation and in the buy-only equation. 
than in Table 7. But I continue to see the basic pattern from Table 7, whereby increases in variables proxying branching opportunities and membership in multibank holding companies have the greatest impact on predicted probabilities.

\section{Affiliate Relationships}

The importance of multibank holding company membership warrants further attention. The most plausible explanation is that the holding company structure facilitates secondary market transactions by lessening information asymmetries between seller and buyer. The "internal loan market" that results is akin to the "internal capital market" described by Houston, James and Marcus (1996) and may help explain why these authors find affiliate loan growth to be negatively related to a bank's own loan growth.

Any evidence regarding an internal loan market will necessarily be indirect. This is because the Call Report provides no information on the counterparties with which a selling or buying bank transacts. Moreover, there are no data at the holding company level equivalent to the bank-level data used here, so it is impossible to directly measure the fraction of secondary market transactions that occur across holding companies. As a result, previous authors have noted the importance of holding company affiliation but stopped there.

It is possible to take the investigation further, though, by determining whether a bank's affiliates are active secondary market participants and using that information to help explain a bank's own sales and/or purchase activity. Since the model I estimate is discrete in nature -distinguishing only among banks that sell, buy, or do both -- I measure affiliate activity in discrete terms as well. I create an indicator variable signifying sales or purchase activity on the part of at least one of a bank's commercial bank affiliates and interact this "active affiliate" variable with the 
indicator for multibank holding company membership. ${ }^{19}$

The results appear in Table 8. For each of the three estimated equations (buy and sell, sell only, and buy only), the table reports coefficients corresponding to the indicator variable representing membership in a multibank holding company and a second variable that interacts the first with and indicator for sales or purchase activity on the part of at least one affiliate bank. The other regression variables are included as well, but their coefficients (similar to those reported above) are not included in Table 8 . For each of the three equations, coefficients on the "active affiliate" interaction term are positive and significant, and the result is robust over time. While still indirect, this evidence goes far toward confirming the notion that holding company membership is important because of the access it provides to potential counterparties -counterparties for whom informational asymmetries are likely to be small.

For banks that only sell or only buy, the positive effect of holding company membership comes entirely from banks with active affiliates. ${ }^{20}$ For banks that both buy and sell, however, the original multibank holding company variable continues to be positive and significant, indicating that holding company membership is important even in the absence of affiliate activity. This result is puzzling. Why should association with affiliates affect secondary market participation if

19 I also tried interaction the holding company indicator variable with three additional variables -- one identifying banks whose affiliates sell and buy, a second identifying banks whose affiliates only sell, and a third identifying banks whose affiliates only buy. The results did not paint a clear picture. The first and third interactions were significant in the sell-only equation, consistent with the notion that activity on the sell side reflects buy-side activity on the part of affiliates. However, only the first interaction was significant in the sell-and-buy equation, and all three interactions were significant in the buy-only equation.

${ }^{20}$ Membership in a holding company that lacks active affiliates actually reduces the likelihood of "sell-only" behavior. Again, a possible explanation is that "sell only" banks meeting lending limits through sales to correspondent banks tend not to be holding company members. 
those affiliates neither sell nor buy?

One possibility is that affiliates not active in a given year may expect to become active in subsequent years, justifying the existence of loan trading facilities at a given bank. Consistent with this story, the interaction variable pulls additional explanatory power from the multibank holding company variable when the interaction is redefined to reflect affiliate activity in any year during the sample period. But the multibank holding company variable remains significant, indicating the importance of holding company membership even in cases where affiliates are consistently inactive. A second possibility is that holding company membership brings with it some reputational effect that facilitates transactions with non-affiliates as well as affiliates, though the nature of that reputational effect remains an open question. ${ }^{21}$

\section{Conclusion}

Existing tests of the comparative advantage hypothesis are based on empirical models of loan sales or loan purchase volume. When banks both sell and buy loans, however, analyses of sales or purchase volume say little about the importance of comparative advantages in loan origination or loan funding. A better approach is to distinguish banks that only sell loans, banks that only buy loans, and banks that both sell and buy loans from those that do not participate.

A multinomial logit model that groups banks into these four categories provides evidence consistent with both the comparative advantage hypothesis and the diversification hypothesis. Consistent with the comparative advantage hypothesis, banks with ample loan origination opportunities have a higher likelihood of being in the sell-only group relative to the buy-only

${ }^{21}$ I tried including holding company size as an additional regressor, but the significance of holding company membership persisted. 
group and banks with greater funding capacity (stronger capital ratios and lower funding costs) have a higher likelihood of being in the buy-only group relative to the sell-only group. Consistent with the diversification hypothesis, the likelihood of both sales and purchases increases where limitations on statewide branching and interstate expansion restrict opportunities for diversified originations.

The results also suggest that reputational barriers can restrict secondary market activity. Banks with strong credit reputations (proxied by net issuance of standby letters of credit) are more likely to participate on the sell side of the market. Banks belonging to multibank holding companies -- banks for which information asymmetries are less of a problem -- are more likely to participate on both the sell side and the buy side of the market, particularly when their affiliates are secondary market participants.

Having documented the motivations for loan sales and purchases, the advantages of an active secondary market are clear. The market enables banks with profitable lending opportunities but limited lending capacity to originate loans, and it allows banks with excess lending capacity to take advantage of loans originated by other banks. It helps banks with limited opportunities for diversified originations achieve their diversification goals, which in turn, may stimulate lending and reduce risk (Akhavein, Berger, and Humphrey, 1996; Demsetz and Strahan 1997). But there are disadvantages to achieving these goals via the secondary loan market. In particular, information asymmetries complicate transactions among unaffiliated banks.

As of June, 1997, banks gained the ability to branch across state lines. Jayaratne and Strahan (1996; forthcoming) suggest that the ramifications for bank efficiency should be positive and strong. This analysis suggests that there may be ramifications for the size and scope of the 
secondary loan market as well. Interstate branching will provide banks with an alternative means to pursue comparative advantages in loan origination or loan funding and to achieve their diversification goals -- an alternative that is not complicated by the information asymmetries surrounding secondary market transactions. All else equal, increased branching opportunities should reduce secondary market activity for this reason.

At the same time, the consolidation wave associated with interstate branching may have the opposite effect, at least in the short run. Holding company acquisitions should enhance secondary market activity by increasing the fraction of banks with access to within-holding company counterparties. The opposite prediction holds once consolidation goes beyond holding company acquisition and actually eliminates bank charters. The "internal loan market" then becomes unobservable to the researcher, and measured secondary market activity should decline. 


\section{References}

Akhavein, Jalal D. and Allen N. Berger and David B. Humphrey, 1997, The Effects of Bank Megamergers on Efficiency and Prices: Evidence from the Profit Function, Review of Industrial Organization 11, 95-139.

Berger, Allen N. and Anil K. Kashyap and Joseph M. Scalise, 1995, The Transformation of the U.S. Banking Industry: What a Long, Strange Trip It's Been, Brookings Papers on Economic Activity 2, 55-218.

Berger, Allen N. and Gregory F. Udell, 1993, Securitization, Risk, and the Liquidity Problem in Banking, in Michael Klausner and Lawrence White, eds.: Structural Change in Banking (Irwin, Homewood: IL).

Cantor, Richard and Rebecca Demsetz, 1993, Securitization, Loan Sales, and the Credit Slowdown, Federal Reserve Bank of New York Quarterly Review 18:2, 27-38.

Carlstrom, Charles T. and Katherine A. Samolyk, 1995, Loan Sales as a Response to MarketBased Capital Constraints, Journal of Banking and Finance 19, 627-646.

Demsetz, Rebecca, 1993, Recent Trends in Commercial Bank Loan Sales, Federal Reserve Bank of New York Quarterly Review 18:4, 75-78.

Demsetz, Rebecca S., 1994, Evidence on the Relationship Between Regional Economic Conditions and Loan Sales Activity, Proceedings of the 30th Annual Conference on Bank Structure and Competition,370-380.

Demsetz, Rebecca S. and Philip E. Strahan, 1997, Diversification, Size, and Risk at Bank Holding Companies, Journal of Money, Credit, and Banking 29, 300-313.

Gorton, Gary B. and Joseph G. Haubrich, 1990, The Loan Sales Market, in George Kaufman, ed.: Research in Financial Services 2, 85-135.

Gorton, Gary B. and George G. Pennacchi, 1995, Banks and Loan Sales: Marketing Nonmarketable Assets, Journal of Monetary Economics 35, 389-411.

Haubrich, Joseph G. and James B. Thomson, 1996, Loan Sales, Implicit Contracts, and Bank Structure, Review of Quantitative and Financial Accounting 7, 137-162.

Houston, Joel and Christopher James and David Marcus, 1997, Capital Market Frictions and the Role of Internal Capital Markets in Banking, Journal of Financial Economics 46, 135- 
164.

Jayaratne, Jith and Philip E. Strahan, 1996, The Finance-Growth Nexus: Evidence from Bank Branch Deregulation, Quarterly Journal of Economics 111, 639-670.

Jayaratne, Jith and Philip E. Strahan, 1998, Entry Restrictions, Industry Evolution, and Dynamic Efficiency: Evidence from Commercial Banking, Journal of Law and Economics 41, 239273.

Pavel, Christine and David Phillis, 1987, Why Commercial Banks Sell Loans: An Empirical Analysis, Federal Reserve Bank of Chicago Economic Perspectives 14, 3-14.

Pennacchi, George G., 1988, Loan Sales and the Cost of Bank Capital, Journal of Finance 43, 375-396. 
Table 1

Loan Sales and Purchase Activity

Pooled data: 1988-1993

\begin{tabular}{|c|c|}
\hline \multicolumn{2}{|c|}{$\mathrm{N}=70,490$} \\
\hline $\begin{array}{l}\text { Buy and Sell } \\
\mathrm{N}=26,804 \\
(38 \text { percent })\end{array}$ & $\begin{array}{c}\text { Sell only } \\
\mathrm{N}=13,252 \\
(19 \text { percent })\end{array}$ \\
\hline $\begin{array}{c}\text { Mean }(\text { assets })=\$ 323 \text { million } \\
\text { Mean (sales/assets })=0.05 \\
\text { Mean }(\text { purchases/assets })=0.05\end{array}$ & $\begin{array}{c}\text { Mean }(\text { assets })=\$ 126 \text { million } \\
\text { Mean }(\text { sales/assets })=0.05\end{array}$ \\
\hline $\begin{array}{l}\text { Buy only } \\
\mathrm{N}=8537 \\
\text { (12 percent) }\end{array}$ & $\begin{array}{c}\text { Neither buy nor sell } \\
\mathrm{N}=21,897 \\
\text { (31 percent) }\end{array}$ \\
\hline $\begin{array}{c}\text { Mean (assets) }=\$ 106 \text { million } \\
\text { Mean }(\text { purchases/assets) }=0.04\end{array}$ & Mean (assets) $=\$ 98$ million \\
\hline
\end{tabular}

Notes: Based on annual observations for all insured domestic commercial banks with less than $\$ 20$ billion in assets and for which all independent variables in Table 2 are available. 
Table 2

Summary Statistics

Pooled Data (1988-1993)

$\mathrm{N}=70,490$

\begin{tabular}{|c|c|c|}
\hline Independent Variables & Mean & Standard Deviation \\
\hline Assets $<\$ 10 \mathrm{~m}$. & 0.05 & 0.22 \\
\hline$\$ 10 \mathrm{~m} .<$ assets $<\$ 25 \mathrm{~m}$ & 0.23 & 0.42 \\
\hline$\$ 25 \mathrm{~m} .<$ assets $<\$ 50 \mathrm{~m}$ & 0.26 & 0.44 \\
\hline$\$ 50 \mathrm{~m} .<$ assets $<\$ 100 \mathrm{~m}$. & 0.23 & 0.42 \\
\hline$\$ 100 \mathrm{~m} .<$ assets $<\$ 500 \mathrm{~m}$. & 0.19 & 0.39 \\
\hline$\$ 500 \mathrm{~m} .<$ assets $<\$ 1 \mathrm{~b}$. & 0.02 & 0.14 \\
\hline$\$ 1$ b. $<$ assets $<\$ 5$ b. & 0.02 & 0.14 \\
\hline$\$ 5 \mathrm{~b} .<$ assets $<\$ 20 \mathrm{~b}$. & 0.01 & 0.08 \\
\hline C\&I loans/assets & 0.10 & 0.08 \\
\hline Equity capital/assets & 0.09 & 0.05 \\
\hline Hot funds/assets & 0.19 & 0.15 \\
\hline State unemployment rate & 5.9 & 1.5 \\
\hline State labor force growth & 0.012 & 0.017 \\
\hline Nonperforming loans/assets & 0.011 & 0.014 \\
\hline Net charge-offs/assets & 0.004 & 0.015 \\
\hline Net standbys/assets & 0.005 & 0.010 \\
\hline Member of multibank holding co. & 0.30 & 0.46 \\
\hline Statewide branching permitted & 0.46 & 0.50 \\
\hline Interstate expansion permitted & 0.89 & 0.31 \\
\hline Number of branches $(\ln )$ & 0.69 & 0.91 \\
\hline
\end{tabular}


Table 3

Multinomial logit estimates for the buy-and-sell group (Equation 1)

(Base group $=$ banks that neither buy nor sell loans)

\begin{tabular}{|c|c|c|c|c|c|c|}
\hline & 1988 & 1989 & 1990 & 1991 & 1992 & 1993 \\
\hline Assets $<\$ 10 \mathrm{~m}$. & $\begin{array}{l}0.282^{*} \\
(1.29)\end{array}$ & $\begin{array}{c}0.192 \\
(0.131)\end{array}$ & $\begin{array}{c}0.108 \\
(0.139)\end{array}$ & $\begin{array}{c}0.113 \\
(0.148)\end{array}$ & $\begin{array}{c}0.265 \\
(0.157)\end{array}$ & $\begin{array}{c}0.243 \\
(0.169)\end{array}$ \\
\hline$\$ 10 \mathrm{~m} .<$ assets $<\$ 25 \mathrm{~m}$. & $\begin{array}{c}0.006 \\
(0.098)\end{array}$ & $\begin{array}{l}-0.055 \\
(0.096)\end{array}$ & $\begin{array}{l}-0.078 \\
(0.098)\end{array}$ & $\begin{array}{l}-0.084 \\
(0.098)\end{array}$ & $\begin{array}{c}0.250^{*} \\
(0.101)\end{array}$ & $\begin{array}{c}0.067 \\
(0.102)\end{array}$ \\
\hline$\$ 25 \mathrm{~m} .<$ assets $<\$ 50 \mathrm{~m}$. & $\begin{array}{c}0.015 \\
(0.090)\end{array}$ & $\begin{array}{l}-0.083 \\
(0.089)\end{array}$ & $\begin{array}{l}-0.119 \\
(0.090)\end{array}$ & $\begin{array}{l}-0.028 \\
(0.089)\end{array}$ & $\begin{array}{c}0.107 \\
(0.091)\end{array}$ & $\begin{array}{l}-0.075 \\
(0.091)\end{array}$ \\
\hline$\$ 50 \mathrm{~m} .<$ assets $<\$ 100 \mathrm{~m}$. & $\begin{array}{l}-0.109 \\
(0.085)\end{array}$ & $\begin{array}{l}-0.171^{*} \\
(0.085)\end{array}$ & $\begin{array}{l}-0.193^{*} \\
(0.085)\end{array}$ & $\begin{array}{l}-0.037 \\
(0.084)\end{array}$ & $\begin{array}{c}0.152 \\
(0.084)\end{array}$ & $\begin{array}{c}0.035 \\
(0.084)\end{array}$ \\
\hline$\$ 500 \mathrm{~m} .<$ assets $<\$ 1 \mathrm{~b}$. & $\begin{array}{l}-0.328 \\
(0.216)\end{array}$ & $\begin{array}{c}0.169 \\
(0.232)\end{array}$ & $\begin{array}{c}0.154 \\
(0.218)\end{array}$ & $\begin{array}{c}0.426^{*} \\
(0.206)\end{array}$ & $\begin{array}{c}0.428^{*} \\
(0.209)\end{array}$ & $\begin{array}{c}0.527^{*} \\
(0.215)\end{array}$ \\
\hline$\$ 1$ b. $<$ assets $<\$ 5$ b. & $\begin{array}{c}0.354 \\
(0.237)\end{array}$ & $\begin{array}{c}0.558^{*} \\
(0.238)\end{array}$ & $\begin{array}{c}0.623^{*} \\
(0.249)\end{array}$ & $\begin{array}{l}0.754 * * \\
(0.245)\end{array}$ & $\begin{array}{c}0.309 \\
(0.236)\end{array}$ & $\begin{array}{c}0.338 \\
(0.241)\end{array}$ \\
\hline$\$ 5$ b. $<$ assets $<\$ 20$ b. & ----- & ----- & $\begin{array}{c}0.642 \\
(0.454)\end{array}$ & $\begin{array}{c}0.890 \\
(0.475)\end{array}$ & $\begin{array}{c}0.157 \\
(0.443)\end{array}$ & $\begin{array}{c}0.574 \\
(0.490)\end{array}$ \\
\hline C\&I loans/assets & $\begin{array}{c}7.06^{* *} \\
(0.351)\end{array}$ & $\begin{array}{c}7.08^{* *} \\
(0.372)\end{array}$ & $\begin{array}{c}8.12 * * \\
(0.401)\end{array}$ & $\begin{array}{c}7.34^{* *} \\
(0.395)\end{array}$ & $\begin{array}{c}8.68^{* *} \\
(0.444)\end{array}$ & $\begin{array}{c}9.52 * * \\
(0.493)\end{array}$ \\
\hline Equity capital/assets & $\begin{array}{l}-7.15^{* *} \\
(0.683)\end{array}$ & $\begin{array}{l}-6.16^{* *} \\
(0.621)\end{array}$ & $\begin{array}{r}-10.8 * * \\
(0.805)\end{array}$ & $\begin{array}{l}-8.28 * * \\
(0.765)\end{array}$ & $\begin{array}{r}-10.3 * * \\
(0.849)\end{array}$ & $\begin{array}{r}-10.9 * * \\
(0.909)\end{array}$ \\
\hline Hot funds/assets & $\begin{array}{c}1.30^{* *} \\
(0.174)\end{array}$ & $\begin{array}{c}1.41 * * \\
(0.194)\end{array}$ & $\begin{array}{c}1.58^{* *} \\
(0.215)\end{array}$ & $\begin{array}{c}1.33 * * \\
(0.226)\end{array}$ & $\begin{array}{c}1.37 * * \\
(0.240)\end{array}$ & $\begin{array}{l}1.21 * * \\
(0.239)\end{array}$ \\
\hline State unemployment rate & $\begin{array}{l}-0.081^{* *} \\
(0.016)\end{array}$ & $\begin{array}{l}-0.029 \\
(0.024)\end{array}$ & $\begin{array}{l}-0.312 * * \\
(0.026)\end{array}$ & $\begin{array}{l}-0.369^{* *} \\
(0.021)\end{array}$ & $\begin{array}{l}-0.310 * * \\
(0.019)\end{array}$ & $\begin{array}{l}-0.340^{* *} \\
(0.023)\end{array}$ \\
\hline State labor force growth & $\begin{array}{l}11.5^{* *} \\
(1.82)\end{array}$ & $\begin{array}{l}-3.91 * \\
(1.94)\end{array}$ & $\begin{array}{c}1.15 \\
(1.38)\end{array}$ & $\begin{array}{l}13.4^{* *} \\
(1.84)\end{array}$ & $\begin{array}{l}10.5 * * \\
(1.93)\end{array}$ & $\begin{array}{l}-2.18 \\
(1.66)\end{array}$ \\
\hline Nonperforming loans/assets & $\begin{array}{c}1.26 \\
(1.80)\end{array}$ & $\begin{array}{l}-3.78 \\
(1.96)\end{array}$ & $\begin{array}{l}-9.19 * * \\
(2.26)\end{array}$ & $\begin{array}{c}-10.6 * * \\
(2.41)\end{array}$ & $\begin{array}{l}-8.24 * * \\
(2.48)\end{array}$ & $\begin{array}{l}-7.69 * * \\
(2.81)\end{array}$ \\
\hline Net charge-offs/assets & $\begin{array}{l}-8.19 * * \\
(3.02)\end{array}$ & $\begin{array}{c}-14.3 * * \\
(3.49)\end{array}$ & $\begin{array}{c}-20.5^{* *} \\
(4.23)\end{array}$ & $\begin{array}{r}-33.1 * * \\
(4.94)\end{array}$ & $\begin{array}{r}-21.1 * * \\
(4.66)\end{array}$ & $\begin{array}{c}-42.3 * * \\
(5.68)\end{array}$ \\
\hline Net standbys/assets & $\begin{array}{l}27.2 * * \\
(4.24)\end{array}$ & $\begin{array}{l}27.3 * * \\
(4.36)\end{array}$ & $\begin{array}{c}5.66 \\
(3.26)\end{array}$ & $\begin{array}{l}13.6 * * \\
(3.93)\end{array}$ & $\begin{array}{l}23.4^{* * *} \\
(4.61)\end{array}$ & $\begin{array}{l}21.3 * * \\
(5.13)\end{array}$ \\
\hline Member of multibank holding co. & $\begin{array}{c}1.36^{* *} \\
(0.058)\end{array}$ & $\begin{array}{c}1.58^{* * *} \\
(0.060)\end{array}$ & $\begin{array}{c}1.41^{* *} \\
(0.061)\end{array}$ & $\begin{array}{c}1.39^{* *} \\
(0.061)\end{array}$ & $\begin{array}{c}1.40^{* *} \\
(0.064)\end{array}$ & $\begin{array}{c}1.55^{* *} \\
(0.066)\end{array}$ \\
\hline Statewide branching permitted & $\begin{array}{l}-0.597 * * \\
(0.077)\end{array}$ & $\begin{array}{l}-0.433 * * \\
(0.057)\end{array}$ & $\begin{array}{l}-0.677 * * \\
(0.055)\end{array}$ & $\begin{array}{l}-0.863 * * \\
(0.058)\end{array}$ & $\begin{array}{l}-0.724 * * \\
(0.059)\end{array}$ & $\begin{array}{l}-0.349^{* *} \\
(0.064)\end{array}$ \\
\hline Interstate expansion permitted & $\begin{array}{l}-0.638^{* *} \\
(0.061)\end{array}$ & $\begin{array}{l}-0.896 * * \\
(0.089)\end{array}$ & $\begin{array}{l}-0.577^{* *} \\
(0.096)\end{array}$ & $\begin{array}{l}-0.133 \\
(0.115)\end{array}$ & $\begin{array}{c}0.001 \\
(0.123)\end{array}$ & $\begin{array}{l}-0.04 \\
(0.261)\end{array}$ \\
\hline Number of branches (ln) & $\begin{array}{l}-0.079 \\
(0.043)\end{array}$ & $\begin{array}{l}-0.131 \text { ** } \\
(0.043)\end{array}$ & $\begin{array}{l}-0.068 \\
(0.044)\end{array}$ & $\begin{array}{c}0.052 \\
(0.045)\end{array}$ & $\begin{array}{l}0.147 * * \\
(0.046)\end{array}$ & $\begin{array}{c}0.026 \\
(0.046)\end{array}$ \\
\hline Constant & $\begin{array}{c}0.284 \\
(0.159)\end{array}$ & $\begin{array}{l}0.514 * * \\
(0.160)\end{array}$ & $\begin{array}{c}2.48^{* *} \\
(0.188)\end{array}$ & $\begin{array}{c}2.48^{* *} \\
(0.189)\end{array}$ & $\begin{array}{l}1.79 * * \\
(0.201)\end{array}$ & $\begin{array}{l}2.28 * * \\
(.0327)\end{array}$ \\
\hline $\mathrm{N}$ & 12,695 & 12,307 & 11,872 & 11,605 & 11,242 & 10,769 \\
\hline Chi-squared & 2671 & 2726 & 2819 & 2850 & 2758 & 2612 \\
\hline Pseudo- $\mathrm{R}^{2}$ & $8.1 \%$ & $8.5 \%$ & $9.1 \%$ & $9.4 \%$ & $9.4 \%$ & $9.3 \%$ \\
\hline
\end{tabular}

Notes: The omitted size category includes banks with between $\$ 100$ million and $\$ 500$ million in assets. Banks having greater than $\$ 5$ billion in assets are grouped with banks having between $\$ 1$ billion and $\$ 5$ billion in assets in 1988 and 1989 because no banks with greater than $\$ 5$ billion in assets were in the buy-but-don't-sell group in those years. Standard errors in parentheses. ** indicates significance at the 1 percent level; * indicates significance at the 5 percent level. 
Pseudo- $\mathrm{R}^{2}$ is calculated as $\left\{1-\left(\log\right.\right.$-likelihood ${ }_{\text {model }} / \log$-likelihood $\left.\left.{ }_{\text {constant only }}\right)\right\}$. 
Table 4

Multinomial logit estimates for the sell-only group (Equation 2)

(Base group=banks that neither buy nor sell loans)

\begin{tabular}{|c|c|c|c|c|c|c|}
\hline & 1988 & 1989 & 1990 & 1991 & 1992 & 1993 \\
\hline Assets $<\$ 10 \mathrm{~m}$. & $\begin{array}{l}0.316^{*} \\
(0.147)\end{array}$ & $\begin{array}{l}0.334^{*} \\
(0.148)\end{array}$ & $\begin{array}{c}0.183 \\
(0.156)\end{array}$ & $\begin{array}{c}0.188 \\
(0.167)\end{array}$ & $\begin{array}{c}0.242 \\
(0.176)\end{array}$ & $\begin{array}{c}0.241 \\
(0.190)\end{array}$ \\
\hline$\$ 10 \mathrm{~m} .<$ assets $<\$ 25 \mathrm{~m}$. & $\begin{array}{l}0.261^{*} \\
(0.112)\end{array}$ & $\begin{array}{c}0.292 * * \\
(0.108)\end{array}$ & $\begin{array}{c}0.102 \\
(0.112)\end{array}$ & $\begin{array}{c}0.201 \\
(0.111)\end{array}$ & $\begin{array}{c}0.193 \\
(0.113)\end{array}$ & $\begin{array}{c}0.148 \\
(0.116)\end{array}$ \\
\hline$\$ 25 \mathrm{~m} .<$ assets $<\$ 50 \mathrm{~m}$. & $\begin{array}{c}0.107 \\
(0.103)\end{array}$ & $\begin{array}{c}0.049 \\
(0.101)\end{array}$ & $\begin{array}{c}0.006 \\
(0.103)\end{array}$ & $\begin{array}{c}0.115 \\
(0.101)\end{array}$ & $\begin{array}{c}0.152 \\
(0.101)\end{array}$ & $\begin{array}{c}0.085 \\
(0.103)\end{array}$ \\
\hline$\$ 50 \mathrm{~m} .<$ assets $<\$ 100 \mathrm{~m}$. & $\begin{array}{l}-0.025 \\
(0.098)\end{array}$ & $\begin{array}{l}-0.114 \\
(0.096)\end{array}$ & $\begin{array}{l}-0.121 \\
(0.097)\end{array}$ & $\begin{array}{c}0.059 \\
(0.094)\end{array}$ & $\begin{array}{c}0.094 \\
(0.094)\end{array}$ & $\begin{array}{c}0.141 \\
(0.094)\end{array}$ \\
\hline$\$ 500 \mathrm{~m} .<$ assets $<\$ 1 \mathrm{~b}$. & $\begin{array}{l}-0.488 \\
(0.256)\end{array}$ & $\begin{array}{l}-0.142 \\
(0.265)\end{array}$ & $\begin{array}{l}-0.246 \\
(0.261)\end{array}$ & $\begin{array}{l}-0.186 \\
(0.248)\end{array}$ & $\begin{array}{l}-0.283 \\
(0.254)\end{array}$ & $\begin{array}{l}-0.132 \\
(0.261)\end{array}$ \\
\hline$\$ 1$ b. $<$ assets $<\$ 5$ b. & $\begin{array}{l}-0.275 \\
(0.276)\end{array}$ & $\begin{array}{l}-0.261 \\
(0.277)\end{array}$ & $\begin{array}{l}-0.455 \\
(0.320)\end{array}$ & $\begin{array}{l}-0.524 \\
(0.311)\end{array}$ & $\begin{array}{l}-1.04 * * \\
(0.327)\end{array}$ & $\begin{array}{l}-0.355 \\
(0.291)\end{array}$ \\
\hline$\$ 5$ b. $<$ assets $<\$ 20$ b. & ----- & ----- & $\begin{array}{l}-1.46^{*} \\
(0.725)\end{array}$ & $\begin{array}{c}-0.913 \\
(0.624)\end{array}$ & $\begin{array}{l}-1.35^{*} \\
(0.618)\end{array}$ & $\begin{array}{l}-0.943 \\
(0.652)\end{array}$ \\
\hline C\&I loans/assets & $\begin{array}{l}5.00 * * \\
(0.385)\end{array}$ & $\begin{array}{l}5.17 * * \\
(0.406)\end{array}$ & $\begin{array}{l}6.34 * * \\
(0.436)\end{array}$ & $\begin{array}{l}5.33 * * \\
(0.429)\end{array}$ & $\begin{array}{l}6.57 * * \\
(0.477)\end{array}$ & $\begin{array}{l}7.57 * * \\
(0.529)\end{array}$ \\
\hline Equity capital/assets & $\begin{array}{l}-4.62 * * \\
(0.684)\end{array}$ & $\begin{array}{l}-4.12 * * * \\
(0.635)\end{array}$ & $\begin{array}{l}-5.17 * * \\
(0.769)\end{array}$ & $\begin{array}{l}-3.88^{* * *} \\
(0.711)\end{array}$ & $\begin{array}{l}-5.18 * * \\
(0.824)\end{array}$ & $\begin{array}{l}-6.32 * * \\
(0.933)\end{array}$ \\
\hline Hot funds/assets & $\begin{array}{c}0.957 * * \\
(0.191)\end{array}$ & $\begin{array}{c}0.811^{* *} \\
(0.219)\end{array}$ & $\begin{array}{l}0.619^{*} \\
(2.50)\end{array}$ & $\begin{array}{l}1.00 * * \\
(0.248)\end{array}$ & $\begin{array}{l}0.553 * \\
(0.273)\end{array}$ & $\begin{array}{c}0.480 \\
(0.275)\end{array}$ \\
\hline State unemployment rate & $\begin{array}{c}-0.087 * * \\
(0.018)\end{array}$ & $\begin{array}{c}-0.089 * * \\
(0.026)\end{array}$ & $\begin{array}{c}-0.175^{* *} \\
(0.029)\end{array}$ & $\begin{array}{c}-0.245^{* *} \\
(0.024)\end{array}$ & $\begin{array}{c}-0.147 * * \\
(0.021)\end{array}$ & $\begin{array}{c}-0.194 * * \\
(0.026)\end{array}$ \\
\hline State labor force growth & $\begin{array}{l}10.7 * * \\
(2.04)\end{array}$ & $\begin{array}{c}4.16 \\
(2.13)\end{array}$ & $\begin{array}{l}0.887 \\
(1.55)\end{array}$ & $\begin{array}{c}11.01 * * \\
(2.07)\end{array}$ & $\begin{array}{c}6.72 * * \\
(2.09)\end{array}$ & $\begin{array}{l}-2.34 \\
(1.86)\end{array}$ \\
\hline Nonperforming loans/assets & $\begin{array}{l}4.51 * \\
(1.93)\end{array}$ & $\begin{array}{c}2.53 \\
(2.04)\end{array}$ & $\begin{array}{c}-1.10 \\
(0.236)\end{array}$ & $\begin{array}{l}0.378 \\
(2.41)\end{array}$ & $\begin{array}{l}-2.49 \\
(2.57)\end{array}$ & $\begin{array}{l}-1.11 \\
(2.76)\end{array}$ \\
\hline Net charge-offs/assets & $\begin{array}{l}-1.99 \\
(3.22)\end{array}$ & $\begin{array}{c}-13.6^{* * *} \\
(3.83)\end{array}$ & $\begin{array}{c}-12.6 * * \\
(4.49)\end{array}$ & $\begin{array}{c}-18.2 * * \\
(5.02)\end{array}$ & $\begin{array}{l}-3.15 \\
(4.39)\end{array}$ & $\begin{array}{c}-15.9^{* * *} \\
(5.24)\end{array}$ \\
\hline Net standbys/assets & $\begin{array}{l}23.6 * * \\
(4.52)\end{array}$ & $\begin{array}{l}23.4 * * \\
(4.67)\end{array}$ & $\begin{array}{c}4.74 \\
(3.26)\end{array}$ & $\begin{array}{l}12.5^{* * *} \\
(4.26)\end{array}$ & $\begin{array}{l}15.9 * * \\
(5.10)\end{array}$ & $\begin{array}{l}18.6 * * \\
(5.45)\end{array}$ \\
\hline Member of multibank holding co. & $\begin{array}{l}0.362^{* *} * \\
(0.070)\end{array}$ & $\begin{array}{l}0.476^{* * *} \\
(0.072)\end{array}$ & $\begin{array}{c}0.230^{* *} \\
(0.076)\end{array}$ & $\begin{array}{c}0.261 * * \\
(0.075)\end{array}$ & $\begin{array}{c}0.305^{* *} \\
(0.077)\end{array}$ & $\begin{array}{c}0.325^{* *} \\
(0.081)\end{array}$ \\
\hline Statewide branching permitted & $\begin{array}{l}-0.079 \\
(0.081)\end{array}$ & $\begin{array}{l}-0.057 \\
(0.062)\end{array}$ & $\begin{array}{c}-0.299 * * \\
(0.061)\end{array}$ & $\begin{array}{c}-0.345^{* *} \\
(0.066)\end{array}$ & $\begin{array}{c}-0.265 * * \\
(0.066)\end{array}$ & $\begin{array}{l}-0.089 \\
(0.073)\end{array}$ \\
\hline Interstate expansion permitted & $\begin{array}{c}-0.357 * * \\
(0.070)\end{array}$ & $\begin{array}{c}-0.602 * * \\
(0.101)\end{array}$ & $\begin{array}{c}-0.484 * * \\
(0.107)\end{array}$ & $\begin{array}{l}-0.024 \\
(0.129)\end{array}$ & $\begin{array}{l}-0.143 \\
(0.137)\end{array}$ & $\begin{array}{l}-0.266 \\
(0.287)\end{array}$ \\
\hline Number of branches (ln) & $\begin{array}{c}0.039 \\
(0.049)\end{array}$ & $\begin{array}{c}0.069 \\
(0.049)\end{array}$ & $\begin{array}{l}0.104 * \\
(0.051)\end{array}$ & $\begin{array}{c}0.209^{* *} \\
(0.051)\end{array}$ & $\begin{array}{c}0.221 * * \\
(0.052)\end{array}$ & $\begin{array}{l}0.128^{*} \\
(0.052)\end{array}$ \\
\hline Constant & $\begin{array}{l}-0.425^{*} \\
(0.177)\end{array}$ & $\begin{array}{c}-0.029 \\
(0.178)\end{array}$ & $\begin{array}{c}0.773 * * \\
(0.207)\end{array}$ & $\begin{array}{c}0.602 * * \\
(0.206)\end{array}$ & $\begin{array}{c}0.173 \\
(0.221)\end{array}$ & $\begin{array}{l}0.793^{*} \\
(0.358)\end{array}$ \\
\hline
\end{tabular}

Notes: The omitted size category captures banks with between $\$ 100$ million and $\$ 500$ million in assets. Banks having greater than $\$ 5$ billion in assets are grouped with banks having between $\$ 1$ billion and $\$ 5$ billion in assets in 1988 and 1989 because no banks with greater than $\$ 5$ billion in assets were in the buy-but-don't-sell group in those years. Standard errors in parentheses. ** indicates significance at the 1 percent level. * indicates significance at the 5 percent level. Number of observations, chi-squared statistics, and pseudo- $\mathrm{R}^{2} \mathrm{~s}$ are reported in Table 3. 
Table 5

Multinomial logit estimates for the buy-only group (Equation 3)

(Base group $=$ banks that neither buy nor sell loans)

\begin{tabular}{|c|c|c|c|c|c|c|}
\hline & 1988 & 1989 & 1990 & 1991 & 1992 & 1993 \\
\hline Assets $<\$ 10 \mathrm{~m}$. & $\begin{array}{l}-0.046 \\
(0.175)\end{array}$ & $\begin{array}{c}0.022 \\
(0.178)\end{array}$ & $\begin{array}{l}-0.514 * * \\
(0.196)\end{array}$ & $\begin{array}{l}-0.484^{*} \\
(0.208)\end{array}$ & $\begin{array}{l}-0.438 \\
(0.231)\end{array}$ & $\begin{array}{l}-0.171 \\
(0.229)\end{array}$ \\
\hline$\$ 10 \mathrm{~m} .<$ assets $<\$ 25 \mathrm{~m}$. & $\begin{array}{l}-0.032 \\
(0.133)\end{array}$ & $\begin{array}{c}0.078 \\
(0.129)\end{array}$ & $\begin{array}{l}-0.251^{*} \\
(0.126)\end{array}$ & $\begin{array}{l}-0.107 \\
(0.124)\end{array}$ & $\begin{array}{c}0.002 \\
(0.129)\end{array}$ & $\begin{array}{l}-0.137 \\
(0.135)\end{array}$ \\
\hline$\$ 25 \mathrm{~m} .<$ assets $<\$ 50 \mathrm{~m}$. & $\begin{array}{c}0.174 \\
(0.122)\end{array}$ & $\begin{array}{c}0.247^{*} \\
(0.119)\end{array}$ & $\begin{array}{l}-0.079 \\
(0.115)\end{array}$ & $\begin{array}{c}0.119 \\
(0.112)\end{array}$ & $\begin{array}{c}0.171 \\
(0.114)\end{array}$ & $\begin{array}{l}-0.037 \\
(0.118)\end{array}$ \\
\hline$\$ 50 \mathrm{~m} .<$ assets $<\$ 100 \mathrm{~m}$. & $\begin{array}{c}0.012 \\
(0.116)\end{array}$ & $\begin{array}{c}0.123 \\
(0.115)\end{array}$ & $\begin{array}{l}-0.029 \\
(0.107)\end{array}$ & $\begin{array}{c}0.023 \\
(0.105)\end{array}$ & $\begin{array}{c}0.255^{*} \\
(0.105)\end{array}$ & $\begin{array}{c}0.255^{*} \\
(0.106)\end{array}$ \\
\hline$\$ 500 \mathrm{~m} .<$ assets $<\$ 1 \mathrm{~b}$. & $\begin{array}{l}-0.701 \\
(0.374)\end{array}$ & $\begin{array}{c}0.226 \\
(0.331)\end{array}$ & $\begin{array}{l}-0.396 \\
(0.327)\end{array}$ & $\begin{array}{l}-0.287 \\
(0.305)\end{array}$ & $\begin{array}{l}-0.055 \\
(0.290)\end{array}$ & $\begin{array}{l}-0.177 \\
(0.314)\end{array}$ \\
\hline$\$ 1$ b. $<$ assets $<\$ 5$ b. & $\begin{array}{l}-0.024 \\
(0.360)\end{array}$ & $\begin{array}{c}0.514 \\
(0.332)\end{array}$ & $\begin{array}{l}-0.086 \\
(0.355)\end{array}$ & $\begin{array}{l}-0.067 \\
(0.351)\end{array}$ & $\begin{array}{c}0.097 \\
(0.307)\end{array}$ & $\begin{array}{l}-1.25^{* *} \\
(0.472)\end{array}$ \\
\hline$\$ 5 \mathrm{~b} .<$ assets $<\$ 20 \mathrm{~b}$. & ----- & ----- & $\begin{array}{l}-1.41 \\
(1.09)\end{array}$ & $\begin{array}{l}-0.643 \\
(0.841)\end{array}$ & $\begin{array}{l}-0.009 \\
(0.586)\end{array}$ & $\begin{array}{c}0.227 \\
(0.631)\end{array}$ \\
\hline C\&I loans/assets & $\begin{array}{c}3.08^{* *} \\
(0.477)\end{array}$ & $\begin{array}{c}2.90^{* * *} \\
(0.505)\end{array}$ & $\begin{array}{c}4.20^{* * *} \\
(0.523)\end{array}$ & $\begin{array}{c}2.85^{* *} \\
(0.520)\end{array}$ & $\begin{array}{c}3.55^{* *} \\
(0.579)\end{array}$ & $\begin{array}{l}4.47^{* * *} \\
(0.647)\end{array}$ \\
\hline Equity capital/assets & $\begin{array}{l}-0.272 \\
(0.489)\end{array}$ & $\begin{array}{l}-1.36^{*} \\
(0.565)\end{array}$ & $\begin{array}{l}-2.38 * * \\
(0.730)\end{array}$ & $\begin{array}{l}-1.72 * * \\
(0.669)\end{array}$ & $\begin{array}{l}-3.47 * * \\
(0.885)\end{array}$ & $\begin{array}{l}-3.37 * * \\
(0.909)\end{array}$ \\
\hline Hot funds/assets & $\begin{array}{c}0.509^{*} \\
(0.509)\end{array}$ & $\begin{array}{c}0.468 \\
(0.249)\end{array}$ & $\begin{array}{c}0.364 \\
(0.284)\end{array}$ & $\begin{array}{l}-0.083 \\
(0.302)\end{array}$ & $\begin{array}{c}0.113 \\
(0.316)\end{array}$ & $\begin{array}{l}-0.480 \\
(0.346)\end{array}$ \\
\hline State unemployment rate & $\begin{array}{c}0.001 \\
(0.021)\end{array}$ & $\begin{array}{l}0.086^{* * *} \\
(0.031)\end{array}$ & $\begin{array}{l}-0.006 \\
(0.034)\end{array}$ & $\begin{array}{l}-0.088 * * \\
(0.025)\end{array}$ & $\begin{array}{l}-0.094 * * \\
(0.024)\end{array}$ & $\begin{array}{l}-0.104 * * \\
(0.029)\end{array}$ \\
\hline State labor force growth & $\begin{array}{c}4.54 \\
(2.44)\end{array}$ & $\begin{array}{l}-0.589 \\
(2.51)\end{array}$ & $\begin{array}{l}4.99 * * \\
(1.78)\end{array}$ & $\begin{array}{l}8.21 * * \\
(2.38)\end{array}$ & $\begin{array}{l}6.54 * * \\
(2.38)\end{array}$ & $\begin{array}{c}3.14 \\
(2.14)\end{array}$ \\
\hline Nonperforming loans/assets & $\begin{array}{c}2.45 \\
(2.41)\end{array}$ & $\begin{array}{l}-3.68 \\
(2.65)\end{array}$ & $\begin{array}{l}-2.55 \\
(2.85)\end{array}$ & $\begin{array}{l}-4.47 \\
(3.06)\end{array}$ & $\begin{array}{c}5.28 \\
(2.82)\end{array}$ & $\begin{array}{c}4.47 \\
(3.14)\end{array}$ \\
\hline Net charge-offs/assets & $\begin{array}{l}-5.68 \\
(4.13)\end{array}$ & $\begin{array}{l}-4.75 \\
(4.38)\end{array}$ & $\begin{array}{r}-12.5^{*} \\
(5.40)\end{array}$ & $\begin{array}{c}-21.2^{* * *} \\
(6.24)\end{array}$ & $\begin{array}{r}-20.3 * * \\
(5.94)\end{array}$ & $\begin{array}{r}-33.5 * * \\
(7.58)\end{array}$ \\
\hline Net standbys/assets & $\begin{array}{c}2.87 \\
(6.19)\end{array}$ & $\begin{array}{l}-2.52 \\
(6.53)\end{array}$ & $\begin{array}{r}-14.7^{*} \\
(5.81)\end{array}$ & $\begin{array}{c}1.54 \\
(5.58)\end{array}$ & $\begin{array}{c}5.74 \\
(6.19)\end{array}$ & $\begin{array}{l}11.1 \\
(6.83)\end{array}$ \\
\hline Member of multibank holding co. & $\begin{array}{c}1.03 * * \\
(0.075)\end{array}$ & $\begin{array}{l}1.17 * * \\
(0.076)\end{array}$ & $\begin{array}{c}1.05^{* *} \\
(0.076)\end{array}$ & $\begin{array}{c}1.13 * * \\
(0.074)\end{array}$ & $\begin{array}{l}1.09 * * \\
(0.078)\end{array}$ & $\begin{array}{l}1.01 * * \\
(0.082)\end{array}$ \\
\hline Statewide branching permitted & $\begin{array}{l}-0.342 * * \\
(0.103)\end{array}$ & $\begin{array}{l}-0.319 * * \\
(0.074)\end{array}$ & $\begin{array}{l}-0.463 * * \\
(0.070)\end{array}$ & $\begin{array}{l}-0.349 * * \\
(0.073)\end{array}$ & $\begin{array}{l}-0.249 * * \\
(0.075)\end{array}$ & $\begin{array}{l}-0.179^{*} \\
(0.083)\end{array}$ \\
\hline Interstate expansion permitted & $\begin{array}{l}-0.369 * * \\
(0.081)\end{array}$ & $\begin{array}{l}-0.598 * * \\
(0.117)\end{array}$ & $\begin{array}{l}-0.674 * * \\
(0.126)\end{array}$ & $\begin{array}{l}-0.302 * \\
(0.145)\end{array}$ & $\begin{array}{l}-0.148 \\
(0.158)\end{array}$ & $\begin{array}{c}0.114 \\
(0.359)\end{array}$ \\
\hline Number of branches (ln) & $\begin{array}{l}-0.108 \\
(0.059)\end{array}$ & $\begin{array}{l}-0.133^{*} \\
(0.058)\end{array}$ & $\begin{array}{l}-0.014 \\
(0.057)\end{array}$ & $\begin{array}{l}-0.002 \\
(0.057)\end{array}$ & $\begin{array}{c}0.039 \\
(0.058)\end{array}$ & $\begin{array}{c}0.034 \\
(0.060)\end{array}$ \\
\hline Constant & $\begin{array}{l}-1.32 * * \\
(0.202)\end{array}$ & $\begin{array}{l}-1.27 * * \\
(0.206)\end{array}$ & $\begin{array}{l}-0.256 \\
(0.233)\end{array}$ & $\begin{array}{l}-0.127 \\
(0.229)\end{array}$ & $\begin{array}{l}-0.443 \\
(0.252)\end{array}$ & $\begin{array}{l}-0.435 \\
(0.430)\end{array}$ \\
\hline
\end{tabular}

Notes: The omitted size category captures banks with between $\$ 100$ million and $\$ 500$ million in assets. Banks having greater than $\$ 5$ billion in assets are grouped with banks having between $\$ 1$ billion and $\$ 5$ billion in assets in 1988 and 1989 because no banks with greater than $\$ 5$ billion in assets were in the buy-but-don't-sell group in those years. Standard errors in parentheses. *** indicates significance at the 1 percent level. * indicates significance at the 5 percent level. Number of observations, chi-squared statistics, and pseudo- $\mathrm{R}^{2} \mathrm{~s}$ are reported in Table 3. 
Table 6

Multinomial logit estimates for the sell-only group

Relative to the buy-only group

(Equation 2 coefficients - Equation 3 coefficients)

\begin{tabular}{|c|c|c|c|c|c|c|}
\hline & 1988 & 1989 & 1990 & 1991 & 1992 & 1993 \\
\hline Assets $<\$ 10 \mathrm{~m}$. & 0.362 & 0.312 & $0.697 * *$ & $0.672 * *$ & $0.680 * *$ & 0.412 \\
\hline$\$ 10 \mathrm{~m} .<$ assets $<\$ 25 \mathrm{~m}$ & $0.293 *$ & 0.214 & $0.353 * *$ & $0.308 *$ & 0.191 & $0.285^{*}$ \\
\hline$\$ 25 \mathrm{~m} .<$ assets $<\$ 50 \mathrm{~m}$ & -0.067 & -0.198 & 0.085 & -0.004 & -0.019 & 0.122 \\
\hline$\$ 50 \mathrm{~m} .<$ assets $<\$ 100 \mathrm{~m}$. & -0.037 & -0.237 & -0.092 & 0.036 & -0.161 & -0.114 \\
\hline$\$ 500 \mathrm{~m} .<$ assets $<\$ 1 \mathrm{~b}$ & 0.213 & -0.368 & 0.150 & 0.101 & -0.228 & 0.045 \\
\hline$\$ 1 \mathrm{~b} .<$ assets $<\$ 5 \mathrm{~b}$. & -0.251 & $-0.775^{*}$ & -0.369 & -0.457 & $-1.14 * *$ & 0.895 \\
\hline$\$ 5$ b. $<$ assets $<\$ 20$ b. & ----- & ----- & -0.050 & -0.270 & $-1.34 *$ & -1.17 \\
\hline C\&I loans/assets & $1.92 * *$ & $2.27 * *$ & $2.14 * *$ & $2.48 * *$ & $3.02 * *$ & $3.10 * *$ \\
\hline Equity capital/assets & $-4.35 * *$ & $-2.76 * *$ & $-2.79 * *$ & $-2.16^{*}$ & -1.71 & $-2.95 * *$ \\
\hline Hot funds/assets & 0.448 & 0.343 & 0.255 & $1.08 * *$ & 0.44 & $0.96 * *$ \\
\hline State unemployment rate & $-0.088 * *$ & $-0.175^{* *}$ & $-0.169 * *$ & $-0.157 * *$ & $-0.053 *$ & $-0.09 * *$ \\
\hline State labor force growth & $6.16 *$ & 4.75 & $-4.10 *$ & 2.80 & 0.180 & $-5.48 *$ \\
\hline Nonperforming loans/assets & 2.06 & $6.21 *$ & 1.45 & 4.85 & $-7.77 *$ & -5.58 \\
\hline Net charge-offs/assets & 3.69 & -8.85 & -0.100 & 3.00 & $17.2 * *$ & $17.6^{*}$ \\
\hline Net standbys/assets & $20.7 * *$ & $25.9 * *$ & $19.4 * *$ & $11.0^{*}$ & 10.2 & 7.50 \\
\hline $\begin{array}{l}\text { Member of multibank holding } \\
\text { co. }\end{array}$ & $-0.668 * *$ & $-0.694 * *$ & $-0.82 * *$ & $-0.869 * *$ & $-0.785^{* *}$ & $-0.685^{* *}$ \\
\hline Statewide branching permitted & $0.263^{*}$ & $0.262 * *$ & $0.164 *$ & 0.004 & -0.016 & 0.090 \\
\hline $\begin{array}{l}\text { Interstate expansion } \\
\text { permitted }\end{array}$ & 0.012 & -0.004 & 0.190 & 0.278 & 0.005 & -0.380 \\
\hline Number of branches $(\ln )$ & $0.147 *$ & $0.202 * *$ & 0.118 & $0.211 * *$ & $0.182 * *$ & 0.094 \\
\hline
\end{tabular}

** denotes differences significant at the 1 percent level. * denotes differences significant at the 5 percent level. 
Table 7

Interpreting Coefficient Magnitudes

Base case probabilities and probabilities at 90th percentiles of the independent variables

"Base case" probabilities are fitted probabilities based on coefficients from a pooled (1988-1993) regression with time fixed effects, using the constant corresponding to 1990 observations, median values of all continuous right-hand-side variables, values of zero for the multibank holding company, statewide branching, and interstate expansion variables, and a value of one for the size dummy corresponding to the median value of assets. Other rows show fitted probabilities based on the same regression coefficients, 90th percentile values of continuous right-hand-side variables, values of one for the multibank holding company, statewide branching, and interstate expansion variables, and a value of one for the size dummy corresponding to the 90th percentile value of assets. In each row, only the stated variable is increased to its 90th percentile (or to one in the case of dummy variables). All other variables are held constant at their median values (or zero in the case of dummy variables).

\begin{tabular}{|c|c|c|c|c|}
\hline & Buy and sell & Sell only & Buy only & Non-participant \\
\hline Base Case & 0.38 & 0.21 & 0.16 & 0.25 \\
\hline Assets & 0.40 & 0.20 & 0.14 & 0.26 \\
\hline C\&I loans/assets & 0.52 & 0.23 & 0.12 & 0.13 \\
\hline Equity capital/assets & 0.31 & 0.21 & 0.18 & 0.31 \\
\hline Hot funds/assets & 0.42 & 0.21 & 0.14 & 0.22 \\
\hline State unemployment rate & 0.32 & 0.20 & 0.18 & 0.30 \\
\hline State labor force growth & 0.39 & 0.21 & 0.16 & 0.24 \\
\hline Nonperforming loans/assets & 0.35 & 0.22 & 0.16 & 0.26 \\
\hline Net charge-offs/assets & 0.36 & 0.21 & 0.16 & 0.28 \\
\hline Net standbys/assets & 0.41 & 0.22 & 0.14 & 0.23 \\
\hline Member of multibank holding co. & 0.61 & 0.11 & 0.18 & 0.10 \\
\hline Statewide branching permitted & 0.27 & 0.23 & 0.16 & 0.35 \\
\hline Interstate expansion permitted & 0.30 & 0.20 & 0.14 & 0.35 \\
\hline Number of branches $(\ln )$ & 0.36 & 0.24 & 0.15 & 0.25 \\
\hline
\end{tabular}


Table 8

Affiliate Activity

Reported coefficients correspond to the indicator variable representing membership in a multibank holding company and a second variable that interacts the first with an indicator for sales or purchase activity on the part of affiliate banks. The other regression variables are included as well, but their coefficients are not reported.

\begin{tabular}{|c|c|c|c|c|c|c|}
\hline & 1988 & 1989 & 1990 & 1991 & 1992 & 1993 \\
\hline \multicolumn{7}{|l|}{$\begin{array}{l}\text { Buy and Sell } \\
\text { (Equation 1) }\end{array}$} \\
\hline $\begin{array}{l}\text { Member of multibank holding } \\
\text { co. }\end{array}$ & $\begin{array}{l}1.15 * * \\
(0.12)\end{array}$ & $\begin{array}{l}1.25 * * \\
(0.12)\end{array}$ & $\begin{array}{l}0.76 * * \\
(0.13)\end{array}$ & $\begin{array}{l}0.98 * * \\
(0.12)\end{array}$ & $\begin{array}{l}0.90 * * \\
(0.13)\end{array}$ & $\begin{array}{l}1.04 * * \\
(0.14)\end{array}$ \\
\hline Member...* active affiliate & $\begin{array}{l}0.34 * * \\
(0.13)\end{array}$ & $\begin{array}{l}0.48 * * \\
(0.13)\end{array}$ & $\begin{array}{l}0.86 * * \\
(0.14)\end{array}$ & $\begin{array}{l}0.58 * * \\
(0.13)\end{array}$ & $\begin{array}{l}0.69 * * \\
(0.14)\end{array}$ & $\begin{array}{l}0.69 * * \\
(0.15)\end{array}$ \\
\hline \multicolumn{7}{|l|}{$\begin{array}{l}\text { Sell Only } \\
\text { (Equation 2) }\end{array}$} \\
\hline $\begin{array}{l}\text { Member of multibank holding } \\
\text { co. }\end{array}$ & $\begin{array}{l}-0.50 * * \\
(0.19)\end{array}$ & $\begin{array}{l}-0.22 \\
(0.18)\end{array}$ & $\begin{array}{l}-0.40 * \\
(0.18)\end{array}$ & $\begin{array}{l}-0.61 * * \\
(0.20)\end{array}$ & $\begin{array}{l}-0.55 * * \\
(0.19)\end{array}$ & $\begin{array}{l}-0.31 \\
(0.20)\end{array}$ \\
\hline Member...* active affiliate & $\begin{array}{l}1.00 * * \\
(0.20)\end{array}$ & $\begin{array}{l}0.82 * * \\
(0.19)\end{array}$ & $\begin{array}{l}0.78 * * \\
(0.19)\end{array}$ & $\begin{array}{l}1.03 * * \\
(0.21)\end{array}$ & $\begin{array}{l}1.02 * * \\
(0.20)\end{array}$ & $\begin{array}{l}0.78 * * \\
(0.21)\end{array}$ \\
\hline \multicolumn{7}{|l|}{$\begin{array}{l}\text { Buy Only } \\
\text { (Equation 3) }\end{array}$} \\
\hline $\begin{array}{l}\text { Member of multibank holding } \\
\text { co. }\end{array}$ & $\begin{array}{c}0.08 \\
(0.20)\end{array}$ & $\begin{array}{c}0.18 \\
(0.20)\end{array}$ & $\begin{array}{l}-0.52 * \\
(0.24)\end{array}$ & $\begin{array}{c}0.08 \\
(0.19)\end{array}$ & $\begin{array}{l}-0.28 \\
(0.22)\end{array}$ & $\begin{array}{c}0.17 \\
(0.21)\end{array}$ \\
\hline Member...* active affiliate & $\begin{array}{l}1.09 * * \\
(0.21)\end{array}$ & $\begin{array}{l}1.14 * * \\
(0.21)\end{array}$ & $\begin{array}{l}1.79 * * \\
(0.24)\end{array}$ & $\begin{array}{l}1.23 * * \\
(0.20)\end{array}$ & $\begin{array}{l}1.59 * * \\
(0.23)\end{array}$ & $\begin{array}{l}1.01 * * \\
(0.22)\end{array}$ \\
\hline
\end{tabular}

** denotes differences significant at the 1 percent level. * denotes differences significant at the 5 percent level. 


\section{THIS TABLE NOT INCLUDED IN TEXT}

Table 7A

Interpreting Coefficient Magnitudes

Base case probabilities and probabilities at 75th percentiles of the independent variables

Base case probabilities are fitted probabilities based on coefficients from a pooled (1988-1993) regression, median values of all continuous right-hand-side variables, values of zero for the multibank holding company, statewide branching, and interstate expansion variables, and a value of one for the size dummy corresponding to the median value of assets. Other rows show fitted probabilities based on the same regression coefficients, 75 th percentile values of continuous right-hand-side variables, values of one for the multibank holding company, statewide branching, and interstate expansion variables, and a value of one for the size dummy corresponding to the 75th percentile value of assets. In each row, only the stated variable is increased to its 75 th percentile (or to one in the case of dummy variables). All other variables are held constant at their median values (or zero in the case of dummy variables).

\begin{tabular}{|l|c|c|c|c|}
\hline & Sell and buy & Sell only & Buy only & Non-participant \\
\hline Base Case & 0.38 & 0.21 & 0.16 & 0.25 \\
Assets & 0.38 & 0.20 & 0.16 & 0.26 \\
C\&I loans/assets & 0.44 & 0.22 & 0.14 & 0.19 \\
Equity capital/assets & 0.35 & 0.21 & 0.17 & 0.27 \\
Hot funds/assets & 0.40 & 0.21 & 0.15 & 0.24 \\
state unemployment rate & 0.34 & 0.20 & 0.17 & 0.29 \\
state labor force growth & 0.38 & 0.21 & 0.16 & 0.25 \\
nonperforming loans/assets & 0.37 & 0.21 & 0.16 & 0.26 \\
net charge-offs/assets & 0.37 & 0.21 & 0.16 & 0.26 \\
net standbys/assets & 0.39 & 0.21 & 0.15 & 0.24 \\
member of multibank holding co. & 0.61 & 0.11 & 0.18 & 0.10 \\
statewide branching permitted & 0.27 & 0.23 & 0.16 & 0.35 \\
interstate expansion permitted & 0.30 & 0.20 & 0.14 & 0.35 \\
Number of branches (ln) & 0.37 & 0.22 & 0.15 & 0.25 \\
& & & & \\
\hline
\end{tabular}

